\title{
The Relation between Assertiveness Levels, Locus of Control and Academic Success of Turkish Language Teacher Candidates
}

\author{
Sibel Dinçyürek ${ }^{1}$, Ahmet Güneyli ${ }^{2}$, Mehmet Çağlar ${ }^{2}$ \\ ${ }^{1}$ Eastern Meditteranean University, Famagusta, North Cyprus \\ ${ }^{2}$ Near East University, Nicosia, North Cyprus \\ Email: sibeldincyurek@hotmail.com
}

Received July $9^{\text {th }}, 2011$; revised October $15^{\text {th }}, 2011$; accepted November $22^{\text {nd }}, 2011$

\begin{abstract}
Before they start their career, candidate teachers must have deep knowledge about the characteristics that a successful teachers should have. The purpose is to create awareness that personal traits of a teacher are critical during education period and to improve and develop these traits. The research is a descriptive one and the basic purpose of this study is to examine the relation between the assertiveness levels and locus of control, on one hand, and academic success, on the other, of senior Turkish teaching students at Eastern Mediterranean University $(\mathrm{n}=276)$. Validity and reliability studies were conducted in order to collect data and "Rathus Assertiveness Schedule" and "Rotter Locus of Control Scale" were used. Percentagefrequency calculations were conducted so as to evaluate the data, cross-reference tables were produced and correlation was examined. In this study, researchers didn't find any correlation between the assertiveness and academic successes of candidate teachers. Likewise, there isn't any relation between locus of control and academic success of candidate teachers.
\end{abstract}

Keywords: Turkish Candidate Teacher; Assertiveness; Locus of Control; Academic Success

\section{Introduction}

The most important element of an education system is teachers. Even if we have the best program, buildings and classrooms, the most appropriate laboratories and libraries, the best course books, and the most modern tools, they are no good if the teacher who will bring them into force is insufficient. For this reason, it is safe to say "a school is as good as its teachers" (Kavcar, 2005). In this paper, the focus is on the personal characteristics of teachers as an element of education system. Characteristics that teachers should possess are grouped under four basic headings: knowledge of the field, teaching knowledge, general culture and personality traits (Brophy, 1981; Demirel, 2006). Studies that focus on personality traits of the teacher as one of these qualifications (Gordon, 1999; Çetin, 2001; Çelikten et al., 2005) emphasized the importance of a variety of personality traits in the education process. According to the results of these studies, teachers who have such personality traits as being patient, objective, kind, sincere, confidant, leader, tolerant, smiling, open to new things and who present a good example to their children with their thoughts and behaviors can be much more successful in their job.

This research is based on the relations between personality traits of teachers and academic success of students. The studies that focused on the impact of personality traits of teachers on student success (Brophy \& Good, 1986; Sünbül, 1996) were reached and it was observed that there was a relation between many personality traits and student success. According to the research results, a teacher, who is warm, timid, caring about his/her work and organized, has positive impact on student success, whereas a teacher who is critical, reproaching, humiliating, provoking competition, gender-discriminating has negative impact on student success.
In this paper the "assertiveness" and "locus of control" personality traits of teachers are taken as reference and the impact of these personality traits on academic success have been examined. Assertiveness is used to mean confidence, self-displaying in an efficient manner, acting effectively, safe behavior, and confident assertiveness. Audacity is a pattern of interpersonal relations developed for ensuring that individuals can defend their rights without disdaining and denying the rights of others. If timidness and aggression are two ends of a spectrum, audacious behavior is placed right in the middle of this spectrum as a compatible and healthy behavior. The basic philosophy of audacity is not people doing everything as they like, but trying to ensure equality. This approach allows for the formation of such bonds as confidence, warmness, intimacy and love between people and individuals to express themselves (VoltanAcar, 2003).

Audacious people know how to say yes or no in an appropriate manner when making their choice. They express what they want in a clear and understable manner. If they suspect that something is wrong, they ask questions and demand explanations. They do not let others use them. They use body language and are sensitive and tolerant in their relations. They are effective, healthy and compliant. They make the decisions and choices of their own lives and realize their aims. They honestly voice out their negative feelings (Beck et al., 1985; Uğurlu, 1994; Greenberg, 2002).

Locus of control is the tendency to perceive the negative or positive events that affect a person as the result of their own behaviors or as an impact of external forces such as luck etc. Internal control is the belief in a person that he/she has the power to affect the events that he/she encounters and their results. External control is, on the other hand, attributing the events and their consequences to powers other than one's self 
(God, luck, fate etc.) (Rotter et al., 1972; Yeşilyaprak, 1990). It is observed that internal-control individuals act more sincerely and deeply in their interpersonal relations compared to external-control individuals. It is a known fact that internal-control individuals spend more time on educative activities, perceive themselves as more effective, confident and independent individuals and lead healthy emotional lives. External-control individuals tend to comply with the society's rules and can believe in anything easily. They are happy with living in line with the will of the majority of the society. In case of a failure, they mostly accuse anyone but themselves (Phares, 1976; Dönmez, 1985; Uzun, 2002).

According to Deluty (2004), audacity and internal-control can be learned and developed. The audacity and internal-control of the teacher can be reflected on the behaviors of the students in the classroom, which is valuable in terms of the teaching-learning process. The studies in the literature usually evaluated the relations between audacity levels and locus of control of students at elementary and secondary education and their academic success. In addition to academic success, especially the relation between gender, age, socio-economic status variables and audacity and locus of control have been examined (Fukuyama \& Greenfield, 1983; Tegin, 1990; Buluş, 1996; Alisinanoğlu, 2003; Serin \& Derin, 2008). However, depending on the deficiency in the literature, the focus of this study is on candidate teachers and the objective is to improve and develop the profession by creating an awareness of the importance of personality traits of teachers in education process. Before they start doing their job, teacher candidates should very well know the personality traits that a successful teacher should possess. From this point on, an evaluation has been made on how the personality traits of teachers (in the context of audacity and locus of control) affect their own academic success.

In this paper, audacity and locus of control personality traits of teachers have been chosen due to the different conclusions reached by studies in the literature which examined the relation between audacity and locus of control and academic success. Some researchers have found out that audacity and locus of control positively affected success (Findley \& Cooper, 1983; Nunn \& Nunn, 1993; Gemi, 1997; Uğurluoğlu, 1996; Cassidy \& Eachus, 2000; Derin, 2006) whereas some others displayed that it had no impact on success (Eisenman \& Platt, 1968; Hjelle, 1970; Yeşilyaprak, 1990; Başol \& Türkoğlu, 2009). The aim of this study is to obtain a new result about this subject, compare it with the conclusions of previous studies, and to obtain data about this data which was not studied before in the example of North Cyprus.

In this study the "audacity" and "locus of control" situations of candidate Turkish language teachers have been examined. Turkish language teaching is based on the teaching of four language skills. Personality traits of teachers are especially determinant in the teaching of verbal language skills (listening and speaking). According to Özbay (2009), Turkish language teachers have to be good listeners, listen by making empathy, and set examples for their students so that they can develop their critical listening skills. Demirel (2002) stated that students could display such negative behaviors as timidness in speakinglearning. Students who are silenced when they want to speak, who cannot find the opportunity to speak and who are punished for speaking can be timid or silent. In this context, it is believed that Turkish language teachers being audacious and with internal locus of control is essential in teaching-learning process in the context that students can identify themselves with the teachers and the subject was found worth studying. To sum up, the basic purpose of this study is to examine the audacity levels and locus of control of Turkish language teaching students at Eastern Mediterranean University and their academic success. The answer to the following sub-problems have been sought in order to reach the general purpose given above:

1) Is the relation between audacity levels and locus of control of Turkish language teacher candidates and their academic success significant?

2) Is the relation between locus of control and academic success of Turkish language teacher candidates and their academic success significant?

\section{Method}

In this study descriptive model was used in order to answer sub-objectives and describe the situation as it is; as a result, quantitative data were obtained. The variables used in this study are assertiveness level, locus of control and academic success. In the study the relations between assertiveness level and locus of control; locus of control and academic success of Turkish language teacher candidates have been displayed and interpreted.

\section{Research Group}

One of the six universities in the country, Eastern Mediterranean University, located in Famagusta district, was included in this study. In the research a total of 276 students who are enrolled at Turkish language teaching department of Eastern Mediterranean University in 2007 were reached. Taking into consideration that senior students at Turkish language teaching department have taken development-learning psychology and guidance course, it was believed that they would be more knowledgeable about the subject and the research group was determined. As age, residence, gender, and education status of parents were not examined, these variables were not needed in this study.

\section{Data Collection Tools}

In this study, "Rathus Assertiveness Schedule" and "Rotter Locus of Control Scale" were used for data collection. Grade averages of teacher candidates were recorded by researchers and the success intervals determined by the status of Eastern Mediterranean University (4.0 - 3.50 high honor, 3.49 - 3.00 honor, $2.99-2.50$ very successful, $2.49-2.00$ successful, 1.99 and below unsuccessful) were used.

Rathus Assertiveness Schedule: It was developed by Rathus in 1977. It measures timidness and audacity behaviors. The scale has 30 items and is aimed for teenagers and adults. The respondents are asked to mark one of the following options for each item: "very much like me" (3), "rather like me" (2), "slightly like me" (1), "slightly unlike me" (-1), "rather unlike me" $(-2)$, "very much unlike me" $(-3)$. The total score which can be received from the scale changes between -90 and 90 . Those who receive 10 and below score are accepted as timid and those who receive above 10 are accepted as "audacious". The scale was translated to Turkish by Voltan-Acar (1980) and its validation was performed by applying the scale to students at Hacettepe University, Child Development and Education De- 
partment. Test-retest reliability coefficient obtained by using Pearson Moments Multiplication correlation formula was found as .92. Split-half reliability was evaluated using Spearman Brown technique and internal consistency was found as .77. Criterion-related validity was, on the other hand, determined by calculating the correlation coefficient (.70) between the selfevaluations of students and their evaluation by their academic advisors (Öner, 2006: pp. 833-834).

Rotter Internal-External Locus of Control Scale: This scale was developed by Rotter in 1966 . The behavior or characteristic that it measures is the situation of generalized control expectations of individual on the endogeneity-exogeneity dimension. The measure consists of 29 items and can be applied to people who completed secondary education. In the scale each item has two options, namely a and b, and the respondent marks the option which best suits him/her. Six of the 29 items cannot be scored as they are extenders. Total score can be between 0 and 23. 0 - 3 means internally controlled, 4 - 11 means standard controlled and 12 - 23 means externally controlled. The scale was translated into Turkish and adapted by Dağ (1990). While internal consistency was being evaluated during reliability calculations, item total correlations varied between .08 and .41 ; however, the scale total scores and correlations of 3rd and 20th items were not found significant. Cronbach alpha coefficient obtained from the sample formed by 532 respondents was found as .71, whereas KR-20 reliability was found as .68 from the sample of 99 respondents. Pearson Moments multiplication coefficient obtained for test-retest reliability was .83. For validity, construct validity and criterion-related validity were made. As a result of the factor analysis, 7 factors which explain $47.7 \%$ of the total variance in scores (lack of chance control, external control in political events, chance control, lack of school success control, lack of control in interpersonal relations, belief in fate, lack of control in political control) were determined. These factors were determined as sufficiently homogeneous and significant resemblance was found with the factors obtained with the original in terms of number and pattern. A relation has been determined between Rosenbaum's Learned Strength Measure which measures self-control and internal control $(-.29, \mathrm{p}<.001)$ and external locus of control and general symptom indicator (GSI) of "symptom crosshatching list" (SCL-90) $(.21, \mathrm{p}<.001)$ (Öner, 2006: pp. 844-846).

\section{Analysis of Data}

The data obtained in the research were analyzed by using appropriate statistical techniques, then explained and interpreted by forming charts. Percentage-frequency calculations were made, cross tables were formed and "Pearson r Coefficient" was calculated. When the statistical data of the study were evaluated, the significance coefficient was taken as $p$ $<.05$.

\section{Findings and Discussion}

1) Is there a significant relation between audacity levels and academic success of Turkish language teaching candidates?

Findings related to the audacity levels and academic success of teacher candidates is provided in Table 1.

When Table 1 is examined, according to the results obtained from Rathus Assertiveness Schedule, 49 of the 58 high honor students $(84.5 \%)$ are timid and $9(15.5 \%)$ are audacious. 68 of the
Table 1.

Cross-table for audacity levels and academic success of Turkish language teacher candidates.

\begin{tabular}{cccc}
\hline Average Grade & $\begin{array}{c}\text { \% Timid between } \\
-90 \text { and }+10\end{array}$ & $\begin{array}{c}\text { \% Audacious } \\
\text { between }+10 \text { and }+90\end{array}$ & Total \\
\hline $4.00-3.50$ High Honor & $49(84.5)$ & $9(15.5)$ & 58 \\
$3.50-3.00$ Honor & $68(74)$ & $24(26)$ & 92 \\
$3.00-2.50$ Very Successful & $46(62.2)$ & $28(37.8)$ & 74 \\
$2.50-2.00$ Successful & $32(72.7)$ & $12(27.3)$ & 44 \\
2.00 and below Unsuccessful & $5(71.4)$ & $2(28.6)$ & 7 \\
Total & 200 & 75 & 275 \\
\hline
\end{tabular}

Note: 1 datum is lost.

92 honor students $(74 \%)$ are timid whereas $24(26 \%)$ are audacious. 46 of the 74 very successful students $(62.2 \%)$ are timid whereas $28(37.8 \%)$ are audacious. 5 of the 7 students $(71.4 \%)$ are timid and $2(28.6 \%)$ are audacious. Most of the 275 candidate teachers $(200$, representing $71.4 \%)$ are timid. The success level with the highest rate of audacious students is $3.00-2.50$ level (very successful). The correlation results for evaluating the relation between audacity levels and academic success of teacher candidates is given in Table 2.

According to the values given in Table 2, the relation between assertiveness levels of senior university students at Turkish language department $(\mathrm{r}=0.092)$ and their academic success $(\mathrm{r}=1.00)$ was found to be insignificant.

This result coincides with some research findings in the literature (Şahin, 2001; Kapanci, 2006) and indicates that there is no relation between assertiveness and academic success. On the other hand, Uğurluoğlu (1996), Gemi (1997) and Gökalan (2000) determined relation between personality traits and academic success of students. According to research findings, the academic success of those students who have high assertiveness levels was found to be high. Tataker (2003) and Güven (2010) concluded that those students who have high academic success perception were highly audacious.

According to the results of several studies conducted abroad, assertiveness has to be taken and evaluated as a skill training for children, teenagers and adults. Researchers conducted on children displayed that audacity education provided some gaining in the affective field compared to academic success. It has become clear that earning audacious behaviors is essential in

Table 2.

Correlation results for audacity level and academic success of Turkish language teacher candidates.

\begin{tabular}{llcc}
\hline Control Variables & & Average Grade & Audacity \\
\hline \multirow{2}{*}{ Average Grade } & Correlation & 1.000 & .092 \\
& Significance (2-Tailed) & & .068 \\
& Df & 0 & 392 \\
& Correlation & .092 & 1.000 \\
Assertiveness & Significance (2-Tailed) & .068 &. \\
& Df & 392 & 0 \\
\hline
\end{tabular}


eliminating such bad habits as nicknaming, compeer bullying, swearing etc. (Horstman, 1986; Perry et al., 1988; Droge \& Stipek, 1993; Embyr \& Luzzo, 1996; Clarke \& Kiselce, 1997; Nichols, 2002). Alberti and Emmons (2002), on the other hand, have put emphasis on those individuals who are audacious in reaching their life-related goals are more successful in general terms.

2) Is there a significant relation between locus of control and academic success of Turkish language teaching candidates?

Findings related to the locus of control and academic success of teacher candidates is provided in Table 3.

When Table 3 is examined, according to the results obtained from locus of control scale, 5 of the 58 high honor students (8.6) have internal locus of control, $32(55.2 \%)$ have standard locus of control and $21(36.2 \%)$ have external locus of control. 4 of the 93 high honor students (4.3\%) have internal locus of control, $60(64.5 \%)$ have standard locus of control and $29(31.2 \%)$ have external locus of control. 4 of the 74 very successful students $(5.4 \%)$ are internal locus of control, $36(48.6 \%)$ have standard locus of control and $34(46 \%)$ have external locus of control. 31 of the 44 successful students $(70.4 \%)$ have standard locus of control and $13(29.6 \%)$ have external locus of control. 3 of the 7 unsuccessful students $(42.8 \%)$ have standard locus of control and $4(57.2 \%)$ have external locus of control. Only 13 of the teacher candidates are internally controlled (4.7). High-honor $(4.00-3.50)$ is the success level with the highest number of internally controlled students. The correlation results for evaluating the relation between locus of control and academic success of teacher candidates is given in Table 4.

According to the values given in Table 4, the relation between locus of control levels of senior university students at Turkish language department $(r=0.057)$ and their academic success $(r=1.00)$ was found to be insignificant.

This finding is consistent with the conclusion of some researches (Eisenman \& Platt, 1968; Hjelle, 1970; Yeşilyaprak, 990; Başol \& Türkoğlu, 2009) and shows that there is no relation between locus of control and academic success. However, when the findings of many studies are examined (Findley \& Cooper, 1983; Nunn \& Nunn, 1993; Cassidy \& Eachus, 2000; Derin, 2006), it can be determined that students tend to associate themselves with their successes whereas they tend to associate external forces with their failures, and that internal-control and success rate act in the same direction.

\section{Conclusion and Suggestions}

In this paper it has been found out that there is no significant relation between assertiveness levels and academic success of Turkish language teacher candidates. Likewise, it has also been found out that there is no significant relation between locus of control and academic success of Turkish language teacher candidates. Different results have been obtained in studies conducted about the relation between academic success and locus of control and assertiveness. In order to make this point more explicit, similar studies have to be adapted to different student, teacher and candidate teacher groups and the results have to be compared. Contribution can be made to the process by conducting experimental studies and the sub-dimensions of assertiveness and locus of control can be obtained and a detailed evaluation can be performed.

Gaining success in education process is highly valuable and methods for increasing success should be emphasized. If an individual believes that his/her personality traits are determinant in his/her success, he/she can critically evaluate most of his/her behaviors and develop himself/herself. Students and teachers alike have to know their personality traits well and reflect that their personality traits can affect their academic success. In addition to assertiveness and locus of control, other personality traits (empathy, self-respect etc.) have to be handled and their relation with academic success should be evaluated. In this context, attention should be paid to create student-centered education environments for ensuring that students know their personality traits better. It is essential that scientific studies on the extent to which and how certain personality traits of teachers affect students and the extent to which and how certain personality traits of students affect their academic success be proliferated.

Teachers of Turkish language are the most important elements of mother tongue education. Language skills with cognitive, emotional and kinesthetic content are earned by the teachers in this field. Teachers of Turkish language can provide opportunities for developing creativity during their teaching activities and play a critical role in training their students as thinking and productive individuals (Leach, 2000; Sever, 2002). However, in order to be able to perform such a mother tongue education, teacher candidates must know that their personality traits can affect first their individual success and teaching skills and, when they begin their career, the academic success of their students. In this study the relation between general success situations and personality traits of Turkish language teaching candidates has been examined; future studies can affect the extent and pattern of the impact of personality traits of students and teachers in teaching-learning environment in development

Table 3.

Cross-table for locus of control and academic success of Turkish language teacher candidates.

\begin{tabular}{|c|c|c|c|c|}
\hline Average Grade & Internal Supervision $(0$ - 3)\% & Standard $(4-11) \%$ & External Supervision $(12-23) \%$ & Total \\
\hline 4.00 - 3.50 High Honor & $5(8.6)$ & $32(55.2)$ & $21(36.2)$ & 58 \\
\hline 3.50 - 3.00 Honor & $4(4.3)$ & $60(64.5)$ & $29(31.2)$ & 93 \\
\hline 3.00 - 2.50 Very Successful & $4(5.4)$ & $36(48.6)$ & $34(46)$ & 74 \\
\hline $2.50-2.00$ Successful & - & $31(70.4)$ & $13(29.6)$ & 44 \\
\hline 2.00 and below Unsuccessful & - & $3(42.8)$ & $4(57.2)$ & 7 \\
\hline Total & 13 & 162 & 101 & 276 \\
\hline
\end{tabular}


Table 4.

Correlation results for locus of control and academic success of Turkish language teacher candidates.

\begin{tabular}{clcc}
\hline Control Variables & & Average Grade & Control \\
\hline Average Grade & Correlation & 1.000 & .057 \\
& Significance (2-Tailed) & - & .261 \\
& Df & 0 & 390 \\
Control & Correlation & .057 & 1.000 \\
& Significance (2-Tailed) & .261 & - \\
& Df & 390 & 0 \\
\hline
\end{tabular}

of listening and speaking skills in Turkish language teaching.

\section{REFERENCES}

Alberti, R., \& ve Emmons, M. (2002). Attlganllk hakkinızı kullanın [Your perfect right: Assertiveness and equality in your life and relationships]. Ankara: Hekimler Yayın Birliği.

Alisinanoğlu, F. (2003). Çocukların denetim odağı ile algıladıkları anne tutumları arasındaki ilişkinin incelenmesi [A study on the relationship between childrens' locus of control and the perception of mother attitudes]. Türk Eğitim Bilimleri Dergisi, 1, 97-107.

Balcı, S. (1997). Lise ögrencilerinin denetim odağ̀ ile sinav kaygısı arasindaki ilişki [Relation between locus of control and test anxiety of highschool students]. Unpublished Master Thesis, Ankara: Gazi University.

Başol, G., \& ve Türkoğlu, G. (2009). Sınıf öğretmeni adaylarının düşünme stilleri ile kontrol odağı durumları arasındaki ilişki. [The relationship between the locus of control and thinking styles of teacher candidates]. Uluslararası Insan Bilimleri Dergisi, 6, 732757.

Beck, S., Collins, L., Overholser, J., \& Terry, K. (1985). A cross-sectional assessment of the relationship of social competence measures to peer friendship and likeability in elementary-age children. Genetic, Social, and General Psychology Monographs, 111, 43-63.

Brophy, J. (1981). Teacher praise: A functional analysis. Review of Educational Reserch, 51, 5-32.

Brophy J., \& Good, T. (1986). Teacher behavior and student achievement. In M. C. Wittrock (Ed.), Handbook of Research on Teaching (3rd ed.). New York: McMillan.

Buluş, M. (1996). Ergen öğrencilerde denetim odağ ve yalnızlı düzeyi ilişkisi [The relationship between locus of control and loneliness level in adolescents]. Unpublished Master Thesis, İzmir: Dokuz Eylul University.

Cassidy, S., \& ve Eachus, P. (2000). Learning style, academic belief systems, self-report student proficiency and academic achievement in higher education. Journal of Educational Psychology, 20, 307-322.

Clarke, E. A., \& Kiselica, M. S. (1997). A systemic counseling approach to the problem of bullying. Elementary School Guidance \& Counseling, 31, 310-346.

Çelikten, M., Şanal, M., \& ve Yeni, Y. (2005). Öğretmenlik mesleği ve özellikleri [The teaching profession and its characteristics]. Erciyes Üniversitesi Sosyal Bilimler Enstitüsü Dergisi, 19, 207-237.

Çetin, Ş. (2001). İdeal öğretmen üzerine bir araştırma [A research about ideal teacher]. Milli Ĕgitim Dergisi, 149. URL (last checked 7 June 2010). http://yayim.meb.gov.tr/dergiler/149/cetin.htm

Deluty, R. H. (2004). Observed and imagined: Poems and essays. Baltimore: Gateway Press.

Demirel, Ö. (2002). Türkçe öğretimi [Turkish teaching]. Ankara: PegemA Yayıncilık.

Demirel, Ö. (2006). Plandan değerlendirmeye ögretme sanatı [The teaching art from planning to evaluation] (10th ed.). Ankara: PegemA Yayıncilık.

Derin, R. (2006). Illköğretim 8. sinıf öğrencilerin problem çözme becerileri ve denetim odă̆ düzeyleri ile akademik başarıları arasındaki ilişki [The relationship between academical achievements, locus of control levels and problem solving skills of primary school eighth class students (İzmir city sample)]. Unpublished Master Thesis, İzmir: Dokuz Eylul University.

Dönmez, A. (1985). Denetim odağı, kendine sayg1 ve üç değişken: Çevre büyüklüğü, yaş ve aile ortamı [Locus of control, self-esteem and three variables: Environment, age and family]. Eğitim ve Bilim Dergisi, 55, 4-14.

Droge, K. L., \& Stipek, D. J. (1993). Children's use of dispositions to predict classmates' behavior. Developmental Psychology, 29, 646654.

Eisenman, R., \& Platt, J. J. (1968). Birth order and sex differences in academic achievement and internal-external control. Journal of General Psychology, 78, 279-285.

Embry, S. L., \& Luzzo, D. A. (1996). The relationship between name-calling and peer beliefs among elementary school children: Implications for school counselors. Elementary School Guidance \& Counseling, 31, 122-131.

Findley, M., \& ve Cooper, H. M. (1983). The relation between locus of control and achievement. Journal of Personality and Social Psychology, 44, 419-427.

Fukuyama, M. A., \& Greenfield, T. K. (1983). Dimensions of assertiveness in an Asian-American student population. Journal of Counseling Psychology, 30, 429-432.

Gemi, A. C. (1997). Lise son sinıf ögrencilerinin atılganlık düzeyini etkileyen bazl faktörler [Some factors which affect the level of assertiveness of the students who are at the last grade of the high schools]. Unpublished Master Thesis, Bursa: Uludağ University.

Gordon, T. (1999). Etkili ögretmenlik eğitimi [Teacher effectiveness training]. İstanbul: Sistem Yayınc1lık.

Gökalan Z. B. (2000). İlkögretim okulu ögrencilerinin (12-14 yass) benlik tasarımı, atılganllk ve kendini aşma düzeyleri ile akademik başarları arasindaki ilişki [The relationship between primary school students self-concept, assertiveness and self-disclosure and their academic success]. Unpublished Master Thesis, Konya: Selçuk University.

Greenberg, J. S. (2002). Comprehensive stress management (7th ed.). New York: McGraw-Hill Companies.

Güven, M. (2010). An analysis of the vocational education undergraduate students' levels of assertiveness and problem-solving skills. Procedia Social and Behavioral Sciences, 2, 2064-2070.

Horstman, A. M. (1986). Social validation of children's assertive and unassertive behavior in peer interactions (social skills). Unpublished Doctoral Dissertation, Missoula: University of Montana.

Hjelle, L. A. (1970). Internal-external control as a determinant of academic achievement. Psychological Reports, 26, 326.

Kapancı, İ. (2006). Sosyal bilgiler ögrretimi ögrencilerinin başarl ve atılganlık düzeylerinin karşılaştırlmalı olarak incelenmesi [Comparative analysis of success and assertiveness levels of students education of social science]. Unpublished Master Thesis, Manisa: Celal Bayar University.

Kavcar, C. (2005). Türkçe-edebiyat eğitimi ve öğretmen yetiştirme [Training of Turkish language teachers]. Symposium about Education Faculties in Turkey and Teacher Training. Ankara: Gazi University.

Leach, J. B. M. (2000). Mother tongue teaching. Routledge International Companion to Education, Chapter 44, 771-800.

Nichols, T. R. (2002). Adolescent social competence: An examination of social skills, social performance and social adjustment with urban minority youth. Unpublished Doctoral Dissertation, Columbia University.

Nunn, G. D., \& Nunn, S. J. (1993). Locus of control and school performance: Some implications for teachers. Education, 113, 636-641.

Öner, N. (2006). Türkiye'de kullanilan psikolojik testlerden örnekler [Psychological Tests in Turkey]. İstanbul: Boğaziçi Üniversitesi Yayınevi.

Özbay, M. (2009). Dinleme Eğitimi [Teaching listening]. Ankara: Öncü Kitap.

Perry, D. G., Kusel, S. J., \& ve Perry, L. C. (1988). Victims of peer aggression. Developmental Psychology, 24, 807-814. 
Phares, E. J. (1976). Locus of control in personality. Manhattan: Kansas State University, General Learning Press.

Rotter, J. B., Change, J. E., \& ve Phares, E. J. (1972). Applications of social learning theory of personality. New York: Holt, Richard and Winston.

Serin, N. B., \& ve Derin, R. (2008). İlköğretim öğrencilerinin kişilerarası problem çözme becerisi algıları ve denetim odağı düzeylerini etkileyen faktörler [The factors affecting primary school students' perceptions of interpersonal problem solving skills and the levels of locus of control]. Uluslararast Insan Bilimleri Dergisi, 8, 1-18.

Sever, S. (2002). Öğretim dili olarak Türkçenin sorunları ve öğretmeöğrenme sürecindeki etkili yaklaşımlar, Türkçenin dünü, bugünü, yarını [Problems of Turkish language and effective ways of learning Turkish]. Ankara Üniversitesi Eğitim Bilimleri Fakültesi Dergisi, 34 , $11-22$.

Sünbül, A. M. (1996). Öğretmen niteliği ve öğretimdeki roller [The qualification of a teacher and teaching roles]. Eğitim Yönetimi, 2, 597-607.

Şahin, N. (2001). Eğitim yöneticisi adaylarının özellikleri ile başarı ve atılganlik düzeyleri [Searching the relation in between assertiveness level and psychological problems of adolescents]. Unpublished Master Thesis, İzmir: Dokuz Eylül University.

Tataker, T. (2003). Ergenlerin atılganlık düzeyi ile ruhsal sorunları arasindaki ilişkinin araştırlması [Searching the relation in between assertiveness level and psychological problems of adolescents]. Un- published Master Thesis, İzmir: Dokuz Eylül University.

Tegin, B. (1990). Üniversite öğrencilerinin atılganlık davranış ve eğilimlerinin cinsiyet ve fakülte değişkenleri açısından incelenmesi [Analyzing assertiveness level of university students through gender and other variables]. Psikoloji Dergisi, 7, 21-31.

Uğurlu, U. (1994). Yetiştirme yurdunda yaşayan ergenler ile ailesiyle birlikte yaşayan ergenlerin özsaygı ile atılganlık düzeyleri açısından karşılaștırlması [Comparsion of assertiveness level and self-respect of adolescents who live with their family and in orphanages]. Unpublished Master Thesis, Erzurum: Atatürk University.

Uğurluoğlu, M. Y. (1996). Lise ögrencilerinde özsayg ile atılgan kişilik özelliği arasindaki ilişkinin incelenmesi [The investigation of the relationship between self-esteem level and assertive personality trait in high-school students]. Unpublished Master Thesis, Trabzon: Karadeniz Teknik University.

Uzun, D. (2002). Resmi ve özel okulöncesi eğitim kurumlarında görev yapan ögretmenlerin özsaygl ve denetim odağı arasındaki ilişkilerin karşılaştırllması [Comparison of relations between self-esteem and locus of control for teachers in public and private preschool education]. Unpublished Master Thesis, Ankara: Hacettepe University.

Voltan-Acar, N. PDR'de Yirmibeș Yll [Twenty five years in guidance and psychological counseling]. Ankara: Nobel Yayın Dağıtım.

Yeșilyaprak, B. (1990). Denetim odağının belirleyicileri ve değișimine ilişkin araştırmalar: Bir eleştirel değerlendirme [Researches about locus of control: A critical analysis]. Psikoloji Dergisi, 7, 41-52. 